From Continental Public Finance to Public Choice: Mapping Continuity

\author{
Jürgen G. Backhaus \\ Krupp Chair in Public Finance and Fiscal Sociology \\ University of Erfurt \\ Nordhäuser Str. 63 \\ 99089 Erfurt \\ Germany \\ tel.: ++49-361-737-4550 \\ fax: ++49-361-737-4559 \\ email: juergen.backhaus@uni-erfurt.de \\ http://www.uni-erfurt.de/finanzwissenschaft
}

and

Richard E. Wagner

Harris Professor of Economics

Department of Economics, MSN 3G4

George Mason University

Fairfax, VA 22030

USA

tel.: ++1-703-993-1132

fax: ++1-703-993-1133

email: rwagner@gmu.edu

http://mason.gmu.edu/ rwagner 


\title{
From Continental Public Finance to Public Choice: Mapping Continuity
}

by

\section{Jürgen G. Backhaus \\ (University of Erfurt)}

\author{
and \\ Richard E. Wagner \\ (George Mason University)
}

\begin{abstract}
:
While government is the object that fiscal theorists examine, the history of public finance reveals two distinct orientations toward that examination. One orientation treats the state as autonomous from or independent of economic processes and institutions. The other orientation treats the state and the economy as interdependent and mutually generated. We describe these orientations as Anglo-Saxon and Continental respectively, out of recognition of the geographical loci where these orientations took shape in the late $19^{\text {th }}$ century. We also note that since the mid- $20^{\text {th }}$ century much of the Continental orientation has been pursued under the rubric of public choice rather than public finance. In this way, the state sponsored economic development perspective of cameralist public finance (including Wicksell (1898)) got lost in the transmutation of public finance into public choice.
\end{abstract}

Keywords: Cameralism, Catallaxy, Fiscal Sociology, Public Choice, Public Entrepreneurship, Science of State

JEL codes: B1, B2, HO, ZO 


\section{From Continental Public Finance to Public Choice: Mapping Continuity ${ }^{1}$}

To define public finance as the study of the economic activities of governments would command consensus among fiscal scholars, for all agree that government comprises the object that fiscal scholars study. That consensus dissolves, however, upon closer inspection. What appears instead are two relatively distinct analytical orientations toward fiscal inquiry, reflecting different conceptualizations of the relationship between the polity and the economy. One orientation, which we label the Anglo-Saxon orientation, conceptualizes the polity as independent of or autonomous from the economy. The other orientation, which we label the Continental orientation, conceptualizes the relationship between polity and economy as mutual and reciprocal.

Within the Anglo-Saxon orientation, fiscal theorizing proceeds independently of political regimes and fiscal institutions. Taxes are treated as sacrifices regardless of the regime within which they are extracted. A fiscal scholar might well acknowledge that regimes differ in how much attention they give to the minimization of sacrifices, but the conditions for minimization are themselves independent of regime. Public finance is thus "the study of government intervention in the marketplace (Jha 1998, p. xii)." Within the Continental orientation, by contrast, public finance is the study of how people participate through political and fiscal institutions to generate fiscal patterns and outcomes (Buchanan 1967 is an exemplary treatment within this orientation). In this, paper we first sketch the origins of the Continental orientation in the work of the cameralists, then describe the emergence of a distinct Continental orientation 
in the late- $19^{\text {th }}$ century, and close by noting how the development of public choice in the second half of the $20^{\text {th }}$ century is really a continuation of the Continental orientation toward public finance.

\section{A Complaint and a Quarrel: Framing the Disjunction}

In his 1896 treatise on public finance, Knut Wicksell complained that the theory of public finance "seems to have retained the assumptions of its infancy, in the seventeenth and eighteenth centuries, when absolute power ruled almost all Europe (1958, p, 82)." Absolute power is the possession of an autonomous ruler or state. Such a state might be ruthlessly despotic or it might be relatively benevolent, but it will be autonomous in any case. Sacrifice theories of taxation can be construed in this setting as recipes for the practice of benevolence toward ruled subjects. Wicksell argued that under parliamentary democracies it made no sense to regard subjects as being ruled, for they participated in their own governance through parliamentary institutions. For Wicksell, the challenge to fiscal theorizing was to map the contours of such governance when government was not an agent of intervention into market-generated economic relationships, but rather was an arena in which people participated in their own governance. What resulted was political economy conceptualized as a seamless garment.

If Wicksell's complaint provides a glimpse into the disjunction between what were to become the Anglo-Saxon and Continental orientations toward public finance, the quarrel between Fredric Benham and Henry Simons over their sharply different evaluations of Antonio De Viti De Marco's treatise on public 
finance exposed that disjunction in stark relief. This quarrel occurred through the dueling book reviews that accompanied the publication in 1934 of Antonio De Viti De Marco's treatise, Principii di economia finanziaria, a book whose central arguments were first formulated in his 1888 book, $\underline{\| \text { carattere teorico }}$ dell'economia finanziaria. De Viti's treatise was a major statement of the continental tradition of public finance, in that it sought to explain the observed phenomena of public finance in terms of economic principles as these play out in a parliamentary institutional setting. It was reviewed in the August 1934 issue of Economica by Fredric Benham, who asserted that De Viti's book "is probably the best treatise on the theory of public finance ever written." Benham laments that sorry state of public finance in England, which was dominated by the choicetheoretic orientation that Wicksell decried (and which Benham associated with Edgeworth and Pigou), could be improved greatly through a strong infusion of De Viti's orientation. Benham also noted the strong complementarity between the approaches taken by De Viti and Wicksell.

In sharp contrast, Henry C. Simons reviewed the English translation of De Viti that appeared in 1936, in the October 1937 issue of the Journal of Political Economy. Simons began by observing that "the Italian literature of public finance has long been held in high esteem; but its claims to distinction have rested mainly upon works which have been inaccessible to those of us who lacked facility with the language. The translations [both German and English translations were being reviewed by Simons ${ }^{2}$ ] of De Viti's famous treatise are thus doubly welcome, for they will make possible a more informed consensus, 
both as to the merits of Italian economics and as to competence of the interpretation and appraisal which it has received in other countries."

After describing this initial sense of eager anticipation, Simons offered his judgment: "Careful reading ... has left the reviewer with no little resentment toward the critics who induced him to search in this treatise for the profound analysis and penetrating insights which it does not contain. The Principii is revealed to him, not as a great book, but as a ... monument to ... confusion." Simons continued by asserting that "there is not a single section or chapter which the reviewer could conscientiously recommend to the competent student searching for genuine insights and understanding."

Simons concludes by taking on Benham's review three years earlier: "If his book is 'the best treatise on the theory of public finance ever written,' one hopes that it may be the last. ... To say that it is distinguished among treatises in its field is to ... comment bitterly on the quality of economic thought in one of its important branches. To call it a great book, however, is a disservice to the cause of higher standards and better orientation in economic inquiry."

This clash of appraisals, moreover, cannot be attributed to any kind of ideological clash over the role of government within society, for all three authors adhered to a generally classically liberal orientation in these matters. Simons worked within the Anglo-Saxon orientation of an autonomous state, with public finance serving as an instrument for appropriate intervention into the economic order. For Simons, improvements in public finance entailed improvements in the instruments of intervention. For De Viti, improvements in public finance would 
correspond to a deeper and more complete understanding of the actual course and pattern of fiscal activity. The intellectual enterprise that De Viti was engaged in was orthogonal to that in which Henry Simons was engaged. There was nothing in De Viti that Simons could regard as providing a means for promoting better intervention, for instead De Viti sought to uncover the underlying economic logic to which governmental action conformed.

\section{Cameralist Origins of Continental Public Finance}

As a field of systematic academic inquiry, public finance arose with the cameralists in central Europe in the $16^{\text {th }}$ century, as surveyed in Dittrich (1974) and Small (1909). Joseph Schumpeter (1954, pp. 143-208) described the cameralists well when he referred to them as "Consultant Administrators." They were both consultants and administrators. They were consultants to the various kings, princes, and other royal personages who ruled throughout those lands. The term cameralist derives from camera or kammer, and refers to the room or chamber where the councellors to the king or prince gathered to do their work. The cameralists were not, however, anything like contemporary academic consultants. They were real-world administrators who were engaged in such activities as managing mines or glass works, as well as holding academic posts. Johnann Heinrich Gottlob von Justi (1717-71) is a good case in point. When he was appointed in Vienna, he was appointed in two capacities. On the one hand, he was to give lectures (in political rhetoric) at the Theresianum, a school the queen and empress had founded for the purpose of training future civil servants. 
Secondly, he was appointed a superintendent of mines. Hence, he prepared two inaugural lectures to be delivered in front of the empress. One lecture outlined what would become his entire rather complex system of cameralism and public administration, and which is presented in Backhaus and Reinert (forthcoming). The other lecture treated the organization of mines.

While cameralism has sometimes been described as a Germanic version of mercantalism, the differences between them are surely more notable than the similarities. Both originated within authoritarian political regimes, and represented efforts to give good counsel to the heads of those regimes. Mercantilism arose among big players on the international stage: the English, the French, the Spanish, and the Dutch. The ability of these powers to reach throughout the world to influence events and terms of trade provided the background for mercantilist thought and practice. The stress upon taxation and the prevalence of rent-seeking and other forms of venality were products of the big-player standing of the mercantile empires.

In contrast, cameralism arose under conditions of high political fragmentation. The cameralist lands were necessarily price takers on the international scene. There was no concern within the cameralist lands about influencing terms of trade, about the use of colonies as instruments of policy, and about one's relative standing among the preponderant powers. The focal point of cameralist concern was on survival of the regime. Survival required a military capacity and economic development, which in turn required the acquisition of 
improved technologies, the improvement of human capital, the creation of new enterprises, and the growth of population.

This concern about development took place within regimes that were both absolutist and severely constrained. The prince was the ruler of his lands, and he could hope to pass his principality along to his eldest son. His ability to do this, however, varied directly with the extent of economic progress within his land. A prince whose land was supporting a growing population of energetic and enterprising subjects would both be wealthier and face better survival prospects than a prince of a land where the population was stagnant or declining, and whose subjects were dull and lethargic. Furthermore, population was mobile in fact, even if it was mostly tied to the land at law through feudal restrictions. Distances between lands were typically short. A peasant who traveled to a new land was not likely to be returned. In fact, it was the common law at the time that after a year plus a day, a peasant who had left the land and stayed in a city would be granted citizen's rights there. The rulers of the cameralist lands faced a competitive labor market. Indeed, the cameralist lands represented a kind of competitive industry among localized governments, much as Tiebout (1956) tried to characterize some 300 years later.

Cameralist public finance treated state lands and enterprises as principal sources of revenue; taxes were a distinctly secondary source. If one were to construct a model of the cameralist vision of the state, it would look like a model of a business firm. The state's lands were potential sources of revenue. Forests ${ }^{3}$ could be harvested, game could be caught, and mines could be built 
and worked. The prince would also sponsor an assortment of commercial enterprises, including such things as the operation of a glassworks or a brewery. Taxes occupied only a secondary position as a source of revenue. Even in the late- $19^{\text {th }}$ century, enterprise revenues and not taxes were the primary source of state revenue in the formerly cameralist lands (Backhaus and Wagner 1987).

The cameralists' general predisposition against taxation as an instrument of public finance reflects an orientation that the state acts as a participant within the economic order. Individuals had their property and the state had its property. The state should be able to use its property to generate the revenues required to finance its activities. Or at least those enterprise revenues should support the major portion of state activity. Some of the cameralists argued that taxes should be earmarked for the support of the military, while all activities concerned with internal development should be financed from the prince's net commercial revenues. In any case, a state contains many business enterprises within its boundaries, and with the state itself operating a subset of those enterprises. It was understood that the state would have significant expenses associated with its activities. These expenses, however, were not to become drains upon the private means of subjects. They were to be met from the lands and enterprises that constituted the state's property. For instance, in order to achieve a particular objective in a sustainable way it was rather common to assign a revenue source such as a vineyard to a public hospital.

Revenues, of course, are only one side of the fiscal account. The cameralists also devoted much thought to the expenditure side. Much of that 
discussion had a kind of capital-theoretic quality to it, where programs of expenditure today would generate increased revenue tomorrow. A great deal of the cameralist emphasis was placed on what is now called human capital, though it would not be appropriate to import too much of a conceptual framework into the cameralist writings. A good deal of this emphasis stemmed from the concern with population. A growing population was desirable, to be sure, but that population in turn had to possess useful skills and talents, to be healthy, and to possess an industrious attitude.

\section{From Cameralism to Continental Public Finance}

In both the cameralist and the mercantilist lands, the material of public finance was conceptualized in choice-theoretic terms. While the rulers of the mercantilist empires faced different opportunities and constraints than did the rulers of the cameralist lands, the phenomena of public finance were the products of ruler's choices in both settings. Throughout the $19^{\text {th }}$ century, however, parliamentary regimes were becoming increasingly common. It was in this context that Wicksell voiced his complaint about the outdated political presumptions of public finance theorizing. To be sure, Wicksell's complaint came perhaps a little late, at least with respect to Continental public finance, for the changes in political regimes were already being accompanied by changes in the orientation of fiscal scholars toward their inquiries, even as illustrated already by Wolff (1740). The phenomena of public finance came increasingly to be treated not as simple choices by some ruler but as the emergent outcomes of complex 
processes of interaction within various forms of parliamentary governance, perhaps as would be conveyed by a notion of catallactical public finance.

In treating a catallactical orientation as the defining characteristic of Continental public finance as it emerged in the late $19^{\text {th }}$ century, we are mapping the world of fiscal scholarship somewhat differently from that presented in Orhan Kayaalp's (2004) treatment of the history of fiscal theorizing. Kayaalp argues that fiscal thought can be organized coherently along five national lines. What we describe as the Anglo-Saxon orientation corresponds to Kayaalp's portrayal of British fiscal thought in terms of the sacrifice approach to taxation. The sacrifice approach is independent of regime and entails an autonomous state. Kayaalp further distinguishes among Italian, German, Austrian, and Swedish fiscal theorizing, all of which we treat under the rubric of Continental public finance because we think the similarities far exceed the differences. Kayaalp associates the benefit approach with Italian public finance, an emphasis on marginal utility with Austrian public finance, and a focus on institutional arrangements for collective choice with Swedish public finance. Yet, all three of these elements were combined throughout the contributions to Continental public finance regardless of national origin. Although at the time scholarly citations were not common, it is obvious that Continental authors read each other's work carefully.

We should also note that Kayaalp treats German public finance as being animated by a vision of an organic state, which would place it outside the Continental orientation and would locate it instead within the domain of sacrifice 
theorizing and an autonomous state. This placement might have characterized a few cameralist writers from a didactical point of view, but it did not characterize German public finance as it took shape during the latter part of the $19^{\text {th }}$ century, as we shall explain below. Indeed, great care must be taken not to misunderstand what was "organic" about the formulations of these authors. While "organic" notions are systematically used in Fichte (1800) and Schäffle (1878), also to some extent in Wagner (1883), they are always used for illustrative purposes only and never as analytical arguments.

It is possible to use a language that speaks of states as responding to public needs without holding a vision of an autonomous or organic state. Object oriented programming provides a good lesson in this respect. Mitchel Resnick (1994) gives a nice example in this respect. Consider a simple computer model of cars moving along a highway. When they enter the highway, the drivers follow the simple rule of speeding up until they get within, say, five car lengths of the preceding car, after which they maintain that distance. This generates a model of an evenly spaced parade of cars crossing the computer screen. Into this stationary state inject some such action as a driver suddenly slowing down, perhaps because he is distracted by a wasp that has flown into his car. This single action creates a chain reaction among the following drivers. A traffic jam results, and this jam is an object in its own right along with the individual cars. The individual cars continue to move forward. The jam itself, however, moves backward. It would not make any sense to speak of the jam as if it were a gigantic car moving backward, for all of the individual cars within the jam are 
moving forward. The jam does reflect the actions of the drivers who comprise the jam, only the relationship among the drivers is interactive and not additive. To treat the jam as an object in its own right is not to treat it as organic or autonomous, for it emerges out of complex patterns of interaction. Modern computational techniques now make it possible to probe the generation of such patterns in ways that could not have been probed a century ago. ${ }^{4}$

As parliaments came to first complement, then replace kings and princes, a transformation occurred in the pattern of property relationships and the associated patterns of governance. The sphere of private property expanded while the property holdings of states contracted. Taxes became more significant sources of revenue; state enterprises provided relatively less revenue. The state as a political entity was no longer independent of the individual citizens whose activities constituted the market economy, for those same citizens represented both the polity and the economy. ${ }^{5}$ This transformation of political regime called for an effort to bring the phenomena of public finance within the same analytical framework as the phenomena of the market economy, taking due account of differences in institutional and organizational arrangements. Hence, scholars within the Continental orientation sought to explain fiscal patterns in terms of such concepts as subjective value, entrepreneurship, and political-economic equilibrium. 


\section{A Quick Excursion into Continental Public Finance}

In this section we shall describe briefly a few examples from continental public finance to illustrate our claim about a common orientation across national boundaries. That orientation centered on the desire to render sensible the fiscal activities of states within a framework of mutual determination of polity and economy. In this section, we shall treat briefly some selected figures who contributed to Continental public finance. Our purpose here is twofold. On the one hand, we seek to characterize the general, commonly held orientation toward public finance. On the other hand, we seek to illustrate some of the differences of analytical detail that found expression within this commonly shared orientation. Hence, we shall first consider some of the seminal Italian contributions, after which we move to the northern end of the continent to examine Knut Wicksell, and then finish our excursion in the center of the continent by examining some German and Austrian contributions.

Italian Fiscal Scholarship. The period roughly bounded by 1880 and 1940 was one of great flourishing for Italian scholarship on public finance. ${ }^{6}$ The Italian scholars treated public finance not just as one specialized field among several within economics, but as an independent object of study, partly in economics but also concerned with politics, law, and administration as well. Central to their analytical framework was the incorporation of the state into the economic process, along with the universal application of such economic categories as utility and profit across all organizational arrangements within society. 
For instance, the ability of political enterprises to expand will depend on their ability to attract patronage. They might attract that patronage through their ability to exploit economies of scale or to provide services that people are willing to support, but which were somehow not being otherwise provided. ${ }^{7}$ This would correspond to standard formulations of public goods theory. They might also attract patronage through subsidizing supporters at the expense of other, less influential members of society, as noted with particular clarity in Giovanni Montemartini ([1900] 1958). The size and scope of political enterprises reflect the same economic principles as operate within the market economy, save only that those principles play out differently within different institutional regimes. The central analytical task in any case was to render sensible the complex and whole economic organization of society, as illustrated crisply in Schumpeter (1911/2003).

The Italian tradition in public finance was soberly realistic. Whether people will support market or state provision of particular services will depend on which source of supply is less expensive to them. State provision may be cheaper for some people while being more expensive for others. If so, divisions of opinion will exist, with the outcome to be resolved through the exercise of political power as this is channeled and organized within some particular political framework. Whether the resulting outcomes are thought to be beautiful or ugly when appraised against some normative standard is beside the point.

Maffeo Pantaleoni (1883) sought to bring the budgetary actions of parliaments within the purview of the economic categories of utility, cost, and 
exchange. Particularly interesting in this regard was the emphasis he gave to the accretion of institutions and procedures over time as economizing devices that rendered manageable what would otherwise have been overwhelming complexity. In this, Pantaleoni recognized that budgeting was incremental and not zero-based. His treatment of parliament could perhaps be assimilated to that of a peculiar form of investment bank. Parliament was an intermediary that facilitated the organization of complex exchanges that brought together people who had programs for which they were seeking support with sources of support for those programs, recognizing, of course, that the offers of support typically were not volunteered.

Some years later, Pantaleoni (1911) treated the state as generating a system of political prices that existed parasitically upon the system of prices that were generated through market relationships. For the most part, each buyer pays the same market price. For political pricing, however, each buyer may well pay a personally unique price. Political prices are in any event discriminatory prices, with the pattern of discrimination being dependent on the particular pattern of taxation being employed. In Pantaleoni's model, political prices could only exist parasitically, with market prices serving as the host. One of the interesting features of Pantaleoni's formulation, noted in Wagner (1997b), is that there is a kind of natural limit to the extent of political pricing that inheres in the parasite-host relationship that political pricing entails.

The classic Italian orientation toward public finance is catallactical. The phenomena of public finance arise through interaction among fiscal participants. 
Those participants might comprise only a small subset of the society, as illustrated by models where ruling classes govern the masses. In other settings, those participants might include everyone in society, as illustrated by models of cooperative democracy. In any case, fiscal phenomena are objects to be subjected to scientific explanation just as surely as are market phenomena. The size of state budgets, the distribution of those budgets across programs, and the sources of revenue that are used are all objects for fiscal explanation within the Italian orientation.

Knut Wicksell and Catallactical Public Finance. Knut Wicksell's contribution to public finance, Finanztheoretische Untersuchungen (1896), contained three essays, the second of which made Wicksell a household word among public finance scholars after it was translated and published as "A New Principle of Just Taxation" in Classics in the Theory of Public Finance, edited by Musgrave and Peacock. The first of Wicksell's three essays undertook an analysis of tax incidence while making use of Böhm-Bawerk's framework of a structure of production. Wicksell's third essay, which occupied nearly half of the book, was an examination of Swedish fiscal history, where Wicksell argued that the New Principle he articulated in his second essay was congruent with various strands of Swedish historical tradition, as well as being capable of implementation in the Sweden of his time.

Wicksell's (1958) second essay, on a new principle of just taxation, has been the overwhelming source of Wicksell's reputation in public finance. This essay asked what kind of institutional framework for parliamentary governance 
might make it possible for the state to act as a productive participant within the economic life of a society. Hardly anyone would dispute the statement that a government should expand its services so long as the value that is created exceeds the cost that people must bear through the value they must sacrifice to pay for those services. But how might this outcome be achieved? Wicksell sought to describe an institutional framework that would promote such an outcome, and in so doing showed how the Pareto principle could be made applicable to the state, which is something that Pareto did not think possible, as Hennipman (1962) notes.

The Wicksellian approach construes the state as a participant within the economic process. The state itself is a process or a framework of rules and procedures that governs human relationships. Fiscal phenomena do not result from the optimizing choices of some exogenous being, but rather emerge through interactions among participants within various fiscal and political processes. Those interactions, in turn, are shaped and constrained by a variety of conventions, institutions, and organizational rules. Fiscal phenomena, like market phenomena, are catallactical and not choice-theoretic phenomena. ${ }^{8}$ The size and extent of governmental activity, within the Wicksellian orientation, is to be explained with references to the same principles that are used to explain other features of economic activity within a society. The same categories of utility, cost, demand, supply, production, and the like are to be brought to bear upon the explanation of fiscal phenomena as are brought to bear on the explanation of market phenomena. 
Wicksell's particular institutional interest was his effort to describe a network of institutional relationships that would make it possible for people in their capacities as taxpayers reasonably to say that their tax payments were directed as they wished. The ability for people to say this would locate government on the same plane as other economic participants. Wicksell assumed that through proportional representation it would be possible to select a parliament that would serve reasonably well as a miniature model of the Swedish population. If this parliament were then bound by a rule of unanimity, its decisions would conform closely to unanimity within the underlying population. The state would participate within the economic process on the same terms as other participants. Its size relative to that of other organizations in society would depend on the effectiveness of its officers in gaining acceptance for proposals in parliament, relative to the ability of other producers to gain favor from people.

Wicksell articulated a principle of unanimity, which he relaxed to a practical rule of approximate unanimity. Wicksell recognized that this shift to approximate unanimity involved the creation of a tradeoff. True unanimity would ensure that people would not have to pay taxes for activities they were not willing to support. But it would also prove costly to any effort of trying truly to work out arrangements for collective support. Some modest movement away from unanimity might, Wicksell thought, be a reasonable compromise to expediency. James Buchanan and Gordon Tullock (1962) subsequently converted this compromise to expediency into a framework for constitutional analysis, and 
which can be traced through to the contemporary scholarship on public choice and constitutional economics, as Richard Wagner (1988) explains.

Wicksell accepted Adolph Wagner's treatment of the state as a form of enterprise, and sought to articulate a framework for governance that would bring principle and practice more closely together. In this, there is an often overlooked relationship between Wicksell's new principle of just taxation and the older tradition from Justi to Wagner that emphasized state entrepreneurship. When the crown offers a particular public service for adoption, it has to propose a scheme of taxation that closely fits the beneficiaries of this service. To the extent

this fit is successful, near unanimity can be secured in parliament. This requires, however, that the landscape of political parties closely corresponds to different social groups which can be clearly distinguished in terms of their demand for particular services, and for purposes of taxation. When that approach fails, and unanimity cannot be secured, the only recourse left is for the crown, acting in its capacity as the producer of goods and services for the public, to act entrepreneurially and finance the activity through the revenue generated by state enterprises.

Staatswissenschaften: The Germanic Science of State. Adolph Wagner (1883), perhaps the best known figure in the Staatswissenschaften tradition, took account of the changes in political and property relationships that had been taking place over the preceding two centuries, while at the same time carrying forward the cameralist orientation toward the state as a participant within society, as against being an intervening agent that acts on society. In particular, 
Wagner conceptualized the state as a type of enterprise located within the economy, though it was of a different sort from most commercial enterprises. In this respect, Wagner argued repeatedly that such state enterprises as railroads and mines can often pursue a leadership role in such areas as occupational safety, stimulating changes among private firms in the process (Backhaus 1997).

To contemporary readers, Wagner is best known for what is now described as Wagner's Law of the increasing relative size of government. These days, Wagner's law is almost uniformly presented as meaning that the income elasticity of demand for state services exceeds unity. A large literature has emerged over roughly the past half century that brings increasingly sophisticated econometrical techniques to bear on probing the income elasticity of demand for state output, as a means of testing the applicability of Wagner's law. The first thing that should be said about this is that Wagner advanced no such formulation. He presented no quantitative statements whatsoever pertaining to income elasticity of demand. What he did was describe the changing patterns of property relationships that had occurred over the preceding few centuries and explore what he thought were their implications for human governance. Over those centuries, state-held property had diminished in economic significance while the sphere of alienable private property had expanded.

This transformation in property relationships led to Wagner's effort to articulate a process of qualitative change in the types of activities undertaken by governments. Qualitative changes might, of course correspond to quantitative increases in some measure of relative economic size, but they need not. For 
instance, people might initially draw their water from wells and deposit waste water in septic fields. With increasing population density, conflicts among people over water would surely intensify, and this in turn would elicit state involvement. That involvement might entail governmental provision of water and sewerage facilities, thus increasing the G/GDP ratio. Alternatively, that involvement might entail governmental facilitation of the formation of new forms of cooperative enterprise that would have little or no impact on a G/GDP ratio. There would be a qualitative change in either case. The further and further extension of the tasks of the state (Aufgaben in German) may very well involve an increase in state spending (Ausgaben in German), but this is not necessarily so. Wagner's emphasis is qualitative and oriented toward public entrepreneurship, which he sees simultaneously as a font of technological innovation and a source of revenue. Indeed, during the years when he wrote, half of the revenues of the Kingdom of Prussia stemmed from its railroad.

The changing character of property relationships and their implications for public finance were central to the legendary debate that took place between the two Austrians, Rudolf Goldscheid and Joseph Schumpeter that are collected in Rudolf Hickel (1976). It was during this debate that Goldscheid coined the term fiscal sociology, the contemporary relevance of which is sketched in Jürgen Backhaus (2002). The particular topic of controversy was what to do with Austria's public debt at the conclusion of World War I and the break up of the Hapsburg Empire. Behind this particular point of contention, however, lay two contrasting perspectives on property and public finance. For Schumpeter, the 
debt could be discharged through an extraordinary tax levy, with the bonds being incinerated and the matter put to rest. In contrast, Goldscheid argued for a recapitalization of the state, after which the state would once again, as in cameralist times, possess property whose revenues would provide the means to support state activities.

This debate about property and the state relates directly to Georgist-type arguments in support of site value taxation. A state that provides services that make location there more desirable will experience rising land values due the resulting increased demand for residency there. A tax on site values would not be a tax in the ordinary sense of the word, but would rather be a charge for those state-supplied services that elicited the increased demand for residency. As Fred Foldvary (1994) and Spencer MacCallum (1970) explain, it is the same for

hotels, shopping centers, and other forms of privately organized community. For instance, a hotel offers a tied sale of a room and such public goods as security services, elevator transit, and park-like amenities. Those public goods increase the demand for residency within the hotel, which is expressed through a higher price that residents are willing to pay.

\section{Public Choice and Continental Public Finance}

The period bounded roughly by 1880 and 1940 was one of great flourishing for Continental public finance. German and Italian were the primary languages through which the Continental orientation was expressed. The calamitous events surrounding Adolf Hitler and World War II had the side effect 
of dispersing many of those contributors elsewhere. This dispersal was accompanied by the rise of English as the lingua franca of economic scholarship. The continental orientation continued to develop in the postwar period, only much of this development now occurred under the name of public choice and not public finance. Indeed, in most of the textbook literature today, public finance is presented as an admixture of Continental and Anglo-Saxon orientations, as illustrated nicely in such textbooks as Cullis and Jones (1998) and Blankart (2001). It is readily apparent from a perusal of contemporary texts in public finance that the two orientations have not been blended, for their respective analytical strands remain distinct and visible, although the texts differ in the relative emphasis they give to the two orientations.

In the postwar period the continental orientation has been carried forward under the heading of public choice. Public choice is not truly a new formation on the intellectual landscape, but rather is a renamed extension of the Continental orientation, as Richard Wagner (2003) explains with reference to Italian fiscal theorizing in particular. For instance, Pantaleoni's (1883) effort to model budgetary outcomes with reference to the average intelligence within parliament, along with his emphasis on incremental accretion of conventions resonates strongly with such recent public choice formulations as probabilistic voting (Hettich and Winer 1999, Coughlin and Nitzan 1981), democratic efficiency (Wittman 1995, Becker 1983), and incremental budgeting (Wildavsky 1984, Kraan 1996). 
Amilcare Puviani's (1903) work on fiscal illusion has never been translated into English, though Buchanan (1967, pp. 126-43) presents a précis. Puviani's work was, however translated into German in 1960, and in his forward to that translation Gunter Schmölders states that "over the last century Italian public finance has had an essentially political science character. The political character of fiscal activity stands always in the foreground [...]. This work [Puviani] is a typical product of Italian public finance, especially a typical product at the end of the $19^{\text {th }}$ century. Above all, it is the science of public finance combined with fiscal politics, in many places giving a good fit with reality." Where Schmölders speaks of political science and political character in connection with Italian public finance, he was referring to what subsequently came to be called public choice. The continental orientation toward fiscal phenomena exhibits continuous development to the present, only it has undergone a change in name in the postwar period, from public finance to public choice. 


\section{References}

Backhaus, Jürgen G. 1997. Essays on Social Security and Taxation; Gustav von Schmoller and Adolph Wagner Reconsidered. Marburg: Metropolis.

Backhaus, Jürgen G. 2002. "Fiscal Sociology: What For?" The American Journal of Economics and Sociology 61/1: 55-77.

Backhaus, Jürgen and Reinert, Eric, eds. Fortthcoming. Johann Heinrich Gottlob von Justi. Hildesheim: Olms.

Backhaus, Jürgen G. and Wagner, Richard E. 1987. "The Cameralists: A Public Choice Perspective." Public Choice 53: 3-20.

Becker, Gary. 1983. "A Theory of Competition among Pressure Groups for Political Influence." Quarterly Journal of Economics 98: 371-400.

Benham, Fredric. 1934. [Review of Princippi di Economia Finanziaria.] Economica N.S. 1: 364-67.

Blankart, Charles B. 2001. Öffentliche Finanzen in der Demokratie, $4^{\text {th }}$ ed. Munich: Franz Vahlen.

Buchanan, James M. 1967. Public Finance in Democratic Process. Chapel Hill: University of North Carolina Press.

Buchanan, James M. and Tullock, Gordon. 1962. The Calculus of Consent. Ann Arbor: University of Michigan Press.

Coughlin, Peter J. and Nitzan, S. 1981. "Electoral Outcomes with Probabilistic Voting and Nash Social Welfare Maxima." Journal of Public Economics 15: $113-22$. 
Cullis, John G. and Jones, Philip R. 1998. Public Finance and Public Choice, $2^{\text {nd }}$ ed. Oxford: Oxford University Press.

De Viti de Marco, Antonio. 1888. $\underline{\| \text { carattere teorico dell'economia. }}$ Rome:

Pasqualucci.

De Viti de Marco, Antonio. 1936. First Principles of Public Finance. London: Jonathan Cape.

Dittrich, Erhard. 1974. Die deutschen und österreichischen Kameralisten.

Darmstadt: Wissenschaftliche Buchgessellschaft.

Fichte, Johann Gottlieb. 1800. Der geschlossene Handelsstaat. München: Saur.

Foldvary, Fred. 1994. Public Goods and Private Communities. Hants: Edward Elgar.

Hennipman, P. 1982. "Wicksell and Pareto: Their Relationship in the Theory of

Public Finance," History of Political Economy 14: 37-64.

Hettich, Walter and Winer, Stanley. 1999. Democratic Choice and Taxation.

Cambridge: Cambridge University Press.

Hickel, Rudolf, ed. 1976. Finanzkrise des Steuerstaats: Beiträge zur politischen

Ökonomischer Staatsfinanzen. Frankfurt a.M.: Suhrkamp.

Jha, Raghbendra. 1998. Modern Public Economics. London: Routledge.

Kayaalp, Orhan. 2004. The National Element in the Development of Fiscal Theory. New York: Palgrave Macmillan.

Kraan, Dirk-Jan. 1996. Budgetary Decisions: A Public Choice Analysis. Cambridge: Cambridge University Press. 
MacCallum, Spencer. H. 1970. The Art of Community. Menlo Park, CA: Institute for Humane Studies.

Montemartini, Giovanni. 1900. "Le basi fondamentali della scienza finanziaria pura." Giornale degli economisti 21: 555-76. [Translated in Musgrave and Peacock (1958), pp. 137-51.]

Musgrave, Richard A. and Peacock, Alan T., eds. 1958. Classics in the Theory of Public Finance. London: Macmillan.

Pantaleoni, Maffeo. 1883. "Contributo alla teoria del riparto delle spese pubbliche." Rassegna italiana 15: 25-70. [Translated in Musgrave and Peacock (1958), pp. 16-27.]

Pfeiffer, Johann Friederich von. 1781. "Grundris der Forstwissenschaft zum Gebrauch dirigirender Forst- und Kameralbedienten, auch Privatgutsbesitzern. Von dem Verfasser des Lehrbegriffs sämmtlicher ökonomischer und Kameralwissenschaften. "Mannheim: C.F. Schwan.

Pantaleoni, Maffeo. 1911. "Considerazioni sulle proprieta di un sistema di prezzi politici." Giornale degli Economisti 42: 9-29, 114-33.

Puviani, Amilcare. 1903. Teoria della illusione finanziaria. Palermo: Sandron. [German translation: Die Illusionen in der öffentlichen Finanzwirtschaft (Berlin: Duncker \& Humblot, 1960).]

Resnick, Mitchel. 1994. Turtles, Termites, and Traffic Jams. Cambridge: MIT Press.

Schäffle, Albert. 1878. Bau und Leben des socialen Körpers. Tübingen: Laupp. 
Schumpeter, Joseph A. 1911/2003. Theorie der wirtschaftlichen Entwicklung (The Theory of Economic Development). First edition 1911/1912. Chapter 7: Das Gesamtbild der Volkswirtschaft translated as "The Economy as a Whole" in: Industry and Innovation, vol. 9, numbers 1/2, 2002 and in: Backhaus, J. (2003) Joseph Alois Schumpeter Entrepreneurship, Style and Vision. Norwell: Kluwer.

Schumpeter, Joseph A. 1954. History of Economic Analysis. New York: Oxford University Press.

Seckendorff, Ludwig Veit von. 1665. Teutscher Fürsten Stat. Reprint, Glashütten: Auvermann 1976

Simons, Henry C. 1936. [Review of First Principles of Public Finance.] Journal of Political Economy 45: 712-17.

Small, Albion. 1909. The Cameralists: The Pioneers of German Social Polity. New York: Burt Franklin.

Tiebout, Charles M. 1956. "A Pure Theory of Local Expenditures." Journal of Political Economy 64: 416-24.

Wagner, Adolph. 1883. Finanzwissenschaft, $3^{\text {rd }}$ ed. Leipzig, C. F. Winter. Wagner, Richard E. 1988. "The Calculus of Consent: A Wicksellian Retrospective." Public Choice 56: 153-66.

Wagner, Richard E. 1997a. "Choice, Exchange, and Public Finance." American Economic Review, Proceedings 87: 160-63.

Wagner, Richard E. 1997b. "Parasitical Political Pricing, Economic Calculation, and the Size of Government: Variations on a Theme 
by Maffeo Pantaleoni." Journal of Public Finance and Public Choice 15: $135-46$.

Wagner, Richard E. 2003. "Public Choice and the Diffusion of Classic Italian Public Finance." $\Perp$ pensiero economico 11:271-82.

Wicksell, Knut. 1958. "A New Principle of Just Taxation." In Classics in the Theory of Public Finance, R. A. Musgrave and A. T. Peacock, eds. (London:Macmillan, pp. 72-118.

Wicksell, Knut. 1896. Finanztheoretische Untersuchungen debst Darstellung und Kritik des Steuersystems Schwedens. Jena: Gustav Fischer.

Wildavsky, Aaron. 1984. Politics of the Budgetary Process, $4^{\text {th }}$ ed. Boston: Little Brown.

Wolff, Christian Freiherr von. 1740. "Von einer Erwegung der Staatsgeschäfte." In Gesammlete kleine philosophische Schriften. Halle: Renger.

Wittman, Donald. 1995. The Myth of Democratic Failure. Chicago: University of Chicago Press. 


\section{Endnotes}

${ }^{1}$ We should like to thank a number of conference participants for helpful comments and suggestions, and we should especially like to thank an anonymous referee for pointing out a number of ambiguities, the rectification of which has improved greatly the flow of the narrative. ${ }^{2}$ Actually, the 1932 German translation was of a 1928 edition of De Viti's treatise, whereas the English translation was of the 1934 edition, which is also the version that Benham reviewed.

${ }^{3}$ Actually, forestry as a science is just one aspect of cameralism. See Pfeiffer (1781).

${ }^{4}$ The entire picture of public finance practice can be told in terms of the driver who had to slow down, but it can also be told from the point of view of those drivers who have their destination in mind and move ahead anyway. To the extent this maneuvering was theory-induced, it is part of what this essay tries to emphasize. See Seckendorff (1665).

${ }^{5}$ Some rulers even in the $20^{\text {th }}$ century were proud not to levy taxes. Letters of tax forgiving are common as Christmas presents shortly before World War I, i.e. in the two Mecklenburgs. The principality of Schaumburg Lippe prides itself of never having levied taxes. The Kingdom of Prussia earned more than $50 \%$ of its revenues from public (competitive) enterprises, not including state monopolies. These revenues, in Wicksell's terms, are consensual, not imposed.

${ }^{6}$ See, for instance, the special 2003 issue of Il pensiero economico italiano devoted to "The Theory of Public Finance in Italy from the Origins to the 1940s."

${ }^{7}$ For instance, because of credit market restrictions, the State was the better debtor in these times.

${ }^{8}$ We should note that we am not using catallactical as a synonym for voluntary, but as an antonym for choice. Fiscal phenomena involve a mixture of exchange and duress, both of which we regard as catallactical, as distinct from choice-theoretic phenomena. See, for instance, Wagner (1997a). 